\title{
Endocrine disruptors in water filters used in the Rio dos Sinos Basin region, Southern Brazil
}

\author{
Furtado, $C M .^{a}$ and von Mühlen, $C .^{b *}$ \\ ${ }^{a}$ Grupo de Pesquisa em Tecnologias Ambientais, Instituto de Ciências Exatas e Tecnológicas - ICET, \\ Universidade Feevale, Rodovia RS-239, 2755, Vila Nova, Novo Hamburgo, RS, Brazil \\ ${ }^{\text {b}}$ Departamento de Química e Ambiental, Faculdade de Tecnologia - FAT, Universidade do Estado do Rio de Janeiro - UERJ, \\ Rodovia Presidente Dutra, KM 298, Polo Industrial, Resende, RJ, Brazil \\ * e-mail: carin.muhlen@uerj.br
}

Received: May 24, 2013 - Accepted: September 9, 2013 - Distributed: May 31, 2015

(With 1 figure)

\begin{abstract}
The activated carbon filter is used in residences as another step in the treatment of drinking water, based on a physical-chemical process to absorb pollutants that are not removed in conventional treatment. Endocrine disruptors (EDCs) are exogenous substances or mixtures of substances that acts on the endocrine system similarly to the endogenously produced hormones, triggering malfunctions and harmful changes to human and animal health. The objective of the present work was to study EDCs through semi-quantitative analysis of residential water filters collected in the region of Rio dos Sinos basin, focusing on two specific classes: hormones and phenols. The solid phase extraction principle was used for the extraction of compounds and gas chromatography coupled with mass spectrometry for the separation and characterization of EDCs. Four samples of residential filters collected from public water distribution and artesian wells, from the cities of Novo Hamburgo and São Leopoldo were analysed. Using the developed methodology, it was possible to detect and comparatively quantify selected EDCs in all studied samples, which indicates the presence of these contaminants in drinking water from different sources.
\end{abstract}

Keywords: charcoal filters, EDCs, POPs, phenols, endocrine disruptors.

\section{Disruptores endócrinos em filtros de água utilizados na região da Bacia Hidrográfica do Rio dos Sinos no Sul do Brasil}

\section{Resumo}

O filtro de carvão ativado é utilizado em residências como mais uma etapa no processo de tratamento da água potável, tendo como base um processo físico-químico para adsorção de poluentes presentes na água que não são removidos no tratamento convencional. Os Disruptores Endócrinos (DEs) são substâncias ou misturas exógenas que atuam no sistema endócrino de maneira similar aos hormônios produzidos endogenamente, desencadeando disfunções e alterações nocivas à saúde humana e animal. O objetivo do presente trabalho foi estudar DEs através da análise semi-quantitativa de amostras de filtros de água coletados na região da bacia do Rio dos Sinos focando em duas classes químicas: hormômios estrogênicos e fenóis. Foram utilizados os princípios da técnica de extração em fase sólida (SPE) para a extração dos compostos, e cromatografia gasosa acoplada à espectrometria de massas para a separação e detecção de DEs. Foram analisadas quatro amostras de filtros residenciais provenientes de água tratada e água de poço artesiano, das cidades de Novo Hamburgo e São Leopoldo. Com o método desenvolvido foi possível detectar e quantificar comparativamente DEs selecionados em todas as amostras estudadas, o que indica a presença desses contaminantes na água de consumo humano oriunda de diferentes fontes.

Palavras-chave: filtro de carvão ativo, DEs, POPs, fenóis e disruptores endócrinos.

\section{Introduction}

Endocrine disruptors (EDCs) are organic pollutants biologically active derived from synthetic hormones, phytoestrogens, endogenous, or synthetic industrial compounds (Bila and Dezotti, 2007). They act in organisms mimicking, antagonizing and/or enhancing the endogenous hormonal activities (Lintelmann et al., 2003; Kim et al., 2007; Wang and Baskin, 2008, Quignot et al., 2012).These pollutants

can trigger mutations causing pathologies related mainly to the endocrine system and also affect the immune and nervous systems (Bila and Dezotti, 2007; Alves et al., 2007).

The main sources of EDCs in the river water are the overuse and excretion by humans of natural or synthetic hormones estrogen (Ghiselli and Jardim, 2007; Torres, 2009; Munaretto, 2009; Fenech et al., 2013), and the large domestic 
agricultural and industrial use of some chlorophenols and alkyl phenols ethoxylates. A significant amount of these compounds can reach water resources through sewage, industrial and agricultural effluents (Torres, 2009; Lopez-Espinosa et al., 2009; Cases et al., 2011).

Despite the known environmental and human health impact caused by water contamination by EDCs and other POPs, few studies have been conducted in Brazil for the diagnosis of these compounds in the environment and in drinking water (Sodré et al., 2010; Jardim et al., 2012; Ribeiro et al., 2012). The National Agency of Water (Brasil, 2009 ) in Brazil established water quality parameters which include the Index of Quality of Raw Water for Public Supply (IAP), and the Water Quality Index (IQA) for the systematic monitoring of surface water. Persistent organic pollutants (POPs) or EDCs (Brasil, 2005; Brasil, 2009) are not included in any of those parameters. According to Decree 2914 from the Ministry of Health (Brasil, 2011), selected POPs and EDCs (59 compounds) are included in the list of compounds monitored in drinking water in Brazil although pharmaceutical drugs and endogenous compounds are not included in this list.

In the Rio dos Sinos basin, one of the most polluted rivers in Brazil (Figueiredo et al., 2010; FEPAM, 2013), the water used to carry those effluents is the same used as for the population water supply for approximately 1.2 million inhabitants, as described elsewhere (Figueiredo et al., 2010). The traditional primary and secondary water treatment is not efficient to remove these kinds of compounds (Auriol et al., 2006). Knowing the inefficiency of the treatment of public water supplies in the region, the population uses charcoal filters to perform domestic treatment to the water supply. These filters have a large accumulation capacity for those compounds, since each filter is used to approximately $600 \mathrm{~L}$ of water. For this reason, it becomes an excellent matrix for the determination of EDCs in the public water supply, either through the supply system or from artesian wells, since it registers the accumulation of those compounds over a 6 month-period.

Despite the fact that this matrix has a high power extraction and concentration of environmental contaminants such as EDCs (Delgado et al., 2012), which are not removed during conventional water treatment, it was not found in the literature any work related to the determination of POPs or EDCs in residential water filters. On the other hand, activated charcoal is a well-known stationary phase for solid phase extraction (SPE) (Mitra, 2003; Vijaya Saradhi et al., 2007), and those extraction techniques can be applied to remove EDCs from this matrix.

In the present work, key environmental contaminants such as EDCs in residential water filters collected in the region of Rio dos Sinos basin were studied, focussing on two specific classes: estrogen hormones (17- $\alpha$-ethinyl estradiol and estrone) and phenols (chlorophenols: 2,5-dichlorophenol, 2,4-dichlorophenol, 2,4,6-trichlorophenol - ethoxylated alkyl phenols: 4-tert-octylphenol and 4-nonylphenol). For the extraction of compounds, the principles of SPE were used, and the characterisation was performed using gas chromatography coupled with quadrupole mass spectrometry (GC/qMS).

\section{Material and Methods}

Among the most used filters in the Rio dos Sinos basin, we highlight those consisting of one single layer of activated carbon Coconut Bay (Cocos nucifera L.) (Purific, 2014). These filters are used in cleaners which replace the 20 litre canisters of water. Each filter has a shelf life of six months and it filters on average 600 litres of water. Four of these charcoal filters used in residences were collected from October 2010 to April 2011. Each one was used for approximately 6 months in each residence. Two charcoal filter samples were collected in Canudos and Ideal neighbourhood in Novo Hamburgo, where water is supplied by the municipal sanitation company. One sample was collected in a residence with artesian water supply in Hamburgo Velho neighbourhood also in Novo Hamburgo. The last sample was collected in downtown São Leopoldo, where water is supplied by the municipal sanitation company from this city. All filters were from the same model and supplier, collected by the company that makes technical assistance of commercial filters.

The materials used in this study were: ultrapurified water (Milli-Q, Millipore); anhydrous sodium sulfate (Nuclear, Brazil); methanol and dichloromethane (both with 99.9\% purity, supplied by Merck, Germany); analytical helium 5.0 (Linde Gases, Canoas, Brazil); analytical standards: 2,4-dichlorophenol (99, 4\%), 2,5-dichlorophenol (99.7\%), 2,4,6 - trichlorophenol (99.6\%), 17- $\alpha$ ethinyl estradiol (99.3\%), and estrone (99.3\%), supplied from Sigma Aldrich (Germany); 4-tert-octylphenol (99.4\%) and 4-nonylphenol (99.9\%) supplied by Supelco (USA). For SPE extractions, $6 \mathrm{~mL}$ glass SPE empty cartridges from Supelco, USA were used.

The equipment used was: a gas chromatograph coupled with a quadrupole mass spectrometer GC/qMS, Model 680T and MS Clarus 600 (Perkin Elmer, USA) with an autosampler; a solid-phase extractor (SPE) model D, Visiprep TM (Supelco, USA), and a vaccum pump (Marconi, Brazil).

Stock solutions were made of a mixture of phenolics (2,4-dichlorophenol, 2,5-dichlorophenol, 2,4,6-trichlorophenol, 4-nonylphenol, 4-tert-octylphenol) and mixtures of hormones (17- $\alpha$-ethinyl estradiol and estrone) at the theoretical concentration of $1000 \mathrm{mg} \mathrm{L}^{-1}$. Phenols were prepared in methanol and hormones in dichloromethane, and stored at $0.8^{\circ} \mathrm{C}$ in amber vials. A calibration curve was constructed from the mixing patterns in dichloromethane stock solutions using five different concentrations ranging according to DECs analysed (as shown in Table 1).

Each filter sample was opened with the aid of a saw, and the activated carbon stage was removed and homogenised. For extraction by SPE, $5 \mathrm{~g}$ of charcoal sample were transferred to a glass SPE cartridge, coupled to the SPE extractor and the vacuum pump. $5 \mathrm{~mL}$ of ultrapure water was added to the 
conditioning stage. The system was subjected to vacuum for $5 \mathrm{~min}$ to eliminate the amount of water remaining in the coal. The compounds of interest were eluted with $5 \mathrm{~mL}$ of dichloromethane. The extract was then passed through a column containing $1 \mathrm{~g}$ of anhydrous sodium sulfate, in order to remove the water. The final extract was concentrated under nitrogen $\left(\mathrm{N}_{2}\right)$ to the dried total, and suspended in $500 \mu \mathrm{L}$ of dichloromethane, transferred to glass vials of $1.5 \mathrm{~mL}$ and analysed by GC/qMS. Three replicates were performed with each sample, including the extraction of a blank charcoal filter.

GC/qMS analysis was carried out using helium as a carrier gas at a constant flow rate of $1.0 \mathrm{~mL} \mathrm{~min}^{-1}$, after the pulse injection of $4 \mathrm{~mL} \mathrm{~min}^{-1}$, and solvent cut at $3.13 \mathrm{~min}$. The GC column used was an ELITE-5MS (5\% phenyl, 95\% polymethylsiloxane, Perkin Elmer, Shelton, EUA), with dimensions $30 \mathrm{~m} \times 0.25 \mathrm{~mm}$ i.d. $\times 0.25 \mu \mathrm{m}$ film thickness. Injector and interface temperatures were $280{ }^{\circ} \mathrm{C}$. Then, $2 \mu \mathrm{L}$ of sample was injected using a 1:20 split with an oven temperature program of $80^{\circ} \mathrm{C}$ for $1 \mathrm{~min}$, raised at $5{ }^{\circ} \mathrm{C} / \mathrm{min}$ to $180{ }^{\circ} \mathrm{C}, 5^{\circ} \mathrm{C} / \mathrm{min}$ up to $180^{\circ} \mathrm{C}$, and then $15^{\circ} \mathrm{C}$ up to $270^{\circ} \mathrm{C}$, followed by a final increase of $20^{\circ} \mathrm{C} / \mathrm{min}$ to $300{ }^{\circ} \mathrm{C}$ (held for $2 \mathrm{~min}$ ). Mass spectra were obtained at a mass-to-charge $(\mathrm{m} / \mathrm{z})$ ratio scan ranging from 35 to $320 \mathrm{u}$, with a $70 \mathrm{eV}$ electronic impact, operating with SCAN and Single Ion Monitoring (SIM) modes simultaneously. The SIM mode operated with the selection of three characteristic ions in time windows for each compound monitored (see Table 1). Compounds were identified using SCAN spectra and the NISTMS (Version 2.0, NIST/EPA/NIH, USA) and ADAMS libraries.

\section{Results and Discussion}

Figures of merit were obtained with the developed method for selected EDCs (see Table 1), considering the use of each filter with $600 \mathrm{~L}$ of water, and an average mass of $116 \mathrm{~g}$ of charcoal per filter. All compounds studied presented acceptable linearity in the range studied. From all compounds studied, 2,4,6-trichlorophenol was the only compound listed in Decree 2914 (Brasil, 2011) with established limit of detection (LOD) in water. The LOD obtained for this compound was found more than 1,000 times below the maximum limit established for drinking water $\left(0.2 \mathrm{mg} \mathrm{L}^{-1}\right)$. Although the other six compounds were not listed in Decree 2914, LODs were similar to those obtained for 2,4,6 -trichlorophenol. The proposed method is relatively simpler in comparison to methods used for water analysis, since the concentration effect in the filter increases the detectability of compounds. As a result, compounds accumulated in the filter can be detected when the concentration in water is several times below the detection limit of traditional methods. Although it is not possible to quantify those compounds in water, since the volume of water used in each filter is estimated, and also the degradation effect and irreversible retention was not evaluated, it is possible to detect the presence of those compounds in a larger volume of water used over six months, which can be used for diagnostic investigations.

In a total ion chromatogram (TIC) obtained from Hamburgo Velho sample (see Figure 1), it is important to notice the complexity of the sample and the number of other compounds not identified. It illustrates the possibility of the use of this methodology for screening of several other compounds not listed in the present study.

The concentration of selected EDCs in four filters collected in the Rio dos Sinos basin region are presented (see Table 2) as well as an estimated concentration of those compounds in water, considering the approximate consumption of $600 \mathrm{~L}$ of water per filter.

2,4-dichlorophenol, 2,5-dichlorophenol, and 2,4,6-trichlorophenol were not detected in any of the samples analysed by the proposed method. 4-tert-octylphenol and 4-nonylphenol were detected only in the sample collected from Hamburgo Velho, whose water supply is artesian (as shown in Figure 1). It is interesting to notice that alkylphenols are used to produce detergents, which are commonly used in residential regions such as Hamburgo Velho. As this region presents innumerous old artesian wells, the contamination of ground water can be the cause of the detection of those compounds in this filter. To confirm this affirmative, further studies with a higher number of samples from this region will be necessary, as well as the direct analysis of the water.

In all analysed samples were detected estrone and $17-\alpha$-ethinyl estradiol. It is well known that both compounds detected are human estrogens and their main source of contamination is by the sewage (Auriol et al., 2006). It indicates that there may be contamination in the watershed of the Rio dos Sinos, and possibly the groundwater, in the

Table 1. Retention time $\left(t_{R}\right)$, concentration range $(C R)$, selected ions for the SIM mode, coefficient of determination $\left(\mathrm{R}^{2}\right)$ limits of detection and quantitation (LOD and LOQ, respectively) of EDCs.

\begin{tabular}{ccccccc}
\hline Compound & $\begin{array}{c}\mathbf{t}_{\mathbf{R}} \\
(\mathbf{m i n})\end{array}$ & $\begin{array}{c}\mathbf{C R} \\
\left(\boldsymbol{\mu g} \mathbf{L}^{-\mathbf{1}}\right)\end{array}$ & $\mathbf{m} / \mathbf{z}$ & $\mathbf{R}^{2}$ & $\begin{array}{c}\mathbf{L O D} \\
\left(\boldsymbol{\mu g} \mathbf{L}^{-1}\right)\end{array}$ & $\begin{array}{c}\mathbf{L O Q} \\
\left(\boldsymbol{\mu g} \mathbf{L}^{-1}\right)\end{array}$ \\
\hline 2,4-dichlorophenol & 7.54 & 2.64 to 70.37 & $98,125,164$ & 0.9885 & 0.67 & 2.64 \\
2,5-dichlorophenol & 7.58 & 2.64 to 70.37 & $98,125,162$ & 0.9885 & 0.67 & 2.64 \\
2,4,6- trichlorophenol & 12.01 & 1.60 to 42.69 & $97,132,196$ & 0.9948 & 0.14 & 1.60 \\
4-tert-octylphenol & 17.91 & 0.62 to 12.41 & $107,135,206$ & 0.9962 & 0.14 & 0.62 \\
4-nonylphenol & 23.01 & 1.10 to 21.92 & $77,107,220$ & 0.9978 & 0.12 & 1.10 \\
Estrone & 28.42 & 0.68 to 17.79 & $146,185,270$ & 0.9959 & 0.09 & 0.68 \\
17- $\alpha$-ethinyl estradiol & 28.81 & 0.63 to 16.86 & $160,213,296$ & 0.9938 & 0.32 & 0.63 \\
\hline
\end{tabular}




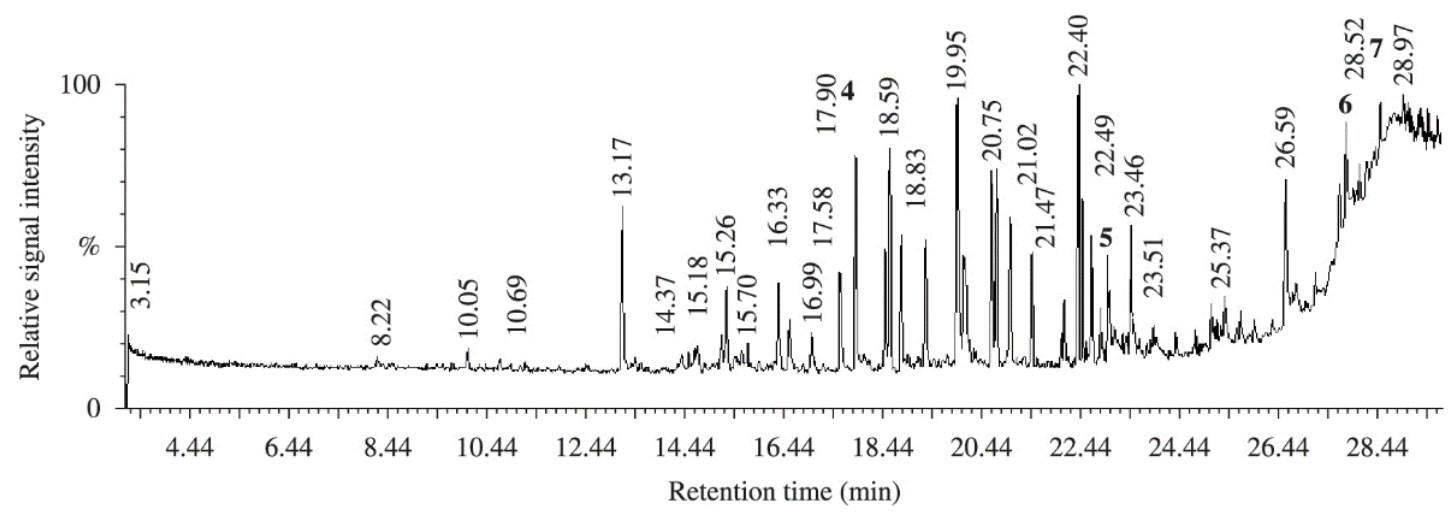

Figure 1. Total ion chromatogram with retention times from a filter sample collected in Hamburgo Velho. Peaks numbered according to identification (see Table 2).

Table 2. Estimated concentration of EDCs studied in samples of filters and extrapolation of values found for water supply.

\begin{tabular}{|c|c|c|c|c|c|}
\hline \multirow{2}{*}{$\begin{array}{c}\text { Peak } \\
\text { number }\end{array}$} & Sample & \multicolumn{2}{|c|}{ Ideal } & \multicolumn{2}{|c|}{ Canudos } \\
\hline & Compound & $\begin{array}{c}\mathrm{C} \\
\text { (mg/filter)* }\end{array}$ & $\begin{array}{c}\text { C water } \\
\left(\mu \mathrm{g} \mathrm{L^{-1 }}\right)^{* *}\end{array}$ & $\begin{array}{c}\mathrm{C} \\
(\mathrm{mg} / \mathrm{filter})^{*}\end{array}$ & $\begin{array}{c}\text { C water } \\
\left(\mu \mathrm{g} \mathrm{L}^{-1}\right)^{* *}\end{array}$ \\
\hline 1 & 2,4-dichlorophenol & $<\mathrm{LOD}$ & $<\mathrm{LOD}$ & $<$ LOD & $<\mathrm{LOD}$ \\
\hline 2 & 2,5-dichlorophenol & $<\mathrm{LOD}$ & $<\mathrm{LOD}$ & $<$ LOD & $<\mathrm{LOD}$ \\
\hline 3 & 2,4,6- trichlorophenol & $<\mathrm{LOD}$ & $<\mathrm{LOD}$ & $<$ LOD & $<\mathrm{LOD}$ \\
\hline 4 & 4-tert-octylphenol & $<\mathrm{LOQ}$ & $<\mathrm{LOQ}$ & $<\mathrm{LOQ}$ & $<$ LOQ \\
\hline 5 & 4-nonylphenol & $<\mathrm{LOQ}$ & $<\mathrm{LOQ}$ & $<\mathrm{LOQ}$ & $<\mathrm{LOQ}$ \\
\hline 6 & estrone & 1.16 & 1.93 & 1.24 & 2.06 \\
\hline 7 & 17- $\alpha$-ethinyl estradiol & 1.30 & 2.16 & 1.48 & 2.46 \\
\hline \multirow[b]{2}{*}{$\begin{array}{c}\text { peak } \\
\text { number }\end{array}$} & Sample & \multicolumn{2}{|c|}{ Hamburgo Velho } & \multicolumn{2}{|c|}{ São Leopoldo } \\
\hline & Compound & $\begin{array}{c}\mathrm{C} \\
(\mathrm{mg} / \mathrm{filter}) *\end{array}$ & $\begin{array}{c}\text { C water } \\
\left(\mu g \mathrm{~L}^{-1}\right)^{* *}\end{array}$ & $\begin{array}{c}\mathrm{C} \\
\text { (mg/filter)* }\end{array}$ & $\begin{array}{c}\text { C water } \\
\left(\mu \mathrm{g} \mathrm{L}^{-1}\right)^{* *}\end{array}$ \\
\hline 1 & 2,4 and 2,5-dichlorophenol & $<\mathrm{LOD}$ & $<$ LOD & $<\mathrm{LOD}$ & $<$ LOD \\
\hline 2 & 2,5-dichlorophenol & $<$ LOD & $<\mathrm{LOD}$ & $<$ LOD & $<\mathrm{LOD}$ \\
\hline 3 & 2,4,6- trichlorophenol & $<\mathrm{LOD}$ & $<\mathrm{LOD}$ & $<$ LOD & $<$ LOD \\
\hline 4 & 4-tert-octylphenol & 0.92 & 1.53 & $<\mathrm{LOQ}$ & $<$ LOQ \\
\hline 5 & 4-nonylphenol & 3.37 & 5.62 & $<\mathrm{LOQ}$ & $<$ LOQ \\
\hline 6 & estrone & 1.37 & 2.28 & 1.25 & 2.09 \\
\hline 7 & 17 - $\alpha$-ethinyl estradiol & 1.61 & 2.68 & 1.42 & 2.36 \\
\hline
\end{tabular}

*Concentration in $\mathrm{mg} /$ filter, considering the average mass of $116 \mathrm{~g}$ of active charcoal per filter. **Estimated concentration in drinking water in $\mu \mathrm{g} \mathrm{L}^{-1}$.

case of the filter collected in a residence that uses artesian well. This contamination in the river water may be related to the daily release of domestic sewage in natura in Rio dos Sinos, since these hormones have no characteristics of bioaccumulation and persistence. These results are consistent with the FEPAM report on Rio dos Sinos water quality during 2010, in Novo Hamburgo and São Leopoldo, where samples were collected (FEPAM, 2013). In this report, the parameter fecal coliforms was class 4 (the worst class, according to CONAMA 357 ) in more than $80 \%$ of samples collected in Novo Hamburgo and São Leopoldo, close to the water threatening stations from those cities. Added to that, both water threatening stations did not use any additional treatment to remove this type of compounds.
These results demonstrated that the proposed method was efficient to study the presence of selected EDCs in charcoal filters, and also it opens up the possibility to correlate the presence of those compounds with water quality over a 6-month period, and possible contamination sources. The number of samples evaluated in the present study was not sufficient to perform a consistent environmental evaluation, but on the other hand, it was capable of confirming the effects of the daily release of effluents in the river water used for the public water supply in Rio dos Sinos basin region. It also demonstrates the importance of monitoring the presence of those estrogens in the drinking water offered for the population, in order to prevent pathologies associated with the intake of those hormones. 
As an example, 17- $\alpha$-ethinylestradiol is considered a potential carcinogen, and also is an EDC. This compound is not monitored in drinking water in Brazil, as regulated by Decree 2.914 (Brasil, 2011). Because of that, there is no maximum limit of those hormones in drinking water to assure potability for human consumption, although it was detected in all filters analysed.

The estimated concentrations of compounds in water presented in this paper can be higher, since it will be necessary to perform future recovery studies to evaluate the amount of each compound retained in the filter.

\section{References}

ALVES, C., FLORES, LC., CERQUEIRA, TS. and TORALLES, MBP., 2007. Exposição ambiental a interferentes endócrinos com atividade estrogênica e sua associação com distúrbios puberais em crianças. Cadernos de Saude Publica, vol. 23, no. 5, p. 1005-1014. http://dx.doi.org/10.1590/S0102-311X2007000500003.

AURIOL, M., FILALI-MEKNASSI, Y., TYAGI, RD., ADAMS, CD. and SURAMPALLI, RY., 2006. Endocrine disrupting compounds removal from wastewater, a new challenge. Process Biochemistry, vol. 41, no. 3, p. 525-539. http://dx.doi.org/10.1016/j. procbio.2005.09.017.

BILA, DM. and DEZOTTI, M., 2007. Desreguladores endócrinos no ambiente: efeitos e conseqüências. Quimica Nova, vol. 30, no. 3, p. 651-666. http://dx.doi.org/10.1590/S0100-40422007000300027.

Brasil, 2005.Resolução $n^{\circ}$ 357, de 15 de março de 2005. Dispõe sobre a classificação dos corpos de água e diretrizes ambientais para o seu enquadramento, bem como estabelece as condições e padrões de lançamento de efluentes, e dá outras providências. Diário Oficial da República Federativa do Brasil, Brasília, 18 mar.

Brasil, 2011. Portaria $n^{\circ} 2.914$, de 12 de dezembro de 2011. Dispõe sobre os procedimentos de controle e de vigilância da qualidade da água para consumo humano e seu padrão de potabilidade. Diário Oficial da República Federativa do Brasil, Brasília.

Brasil. Agência Nacional de Águas - ANA, 2009. Portal da qualidade das águas. ANA. Available from: $<\mathrm{http}: / /$ portalpnqa.ana. gov.br/indicadores-indice-aguas.aspx>. Acess in: 29 Maio. 2015.

CASES, V., ALONSO, V., ARGANDOÑA, V., RODRIGUEZ, M. and PRATS, M., 2011. Endocrine disruptors compounds: A comparison of removal between conventional activated sludge, and membrane bioreactors. Desalination, vol. 272, no. 1-3, p. 240-245. http://dx.doi.org/10.1016/j.desal.2011.01.026.

DELGADO, LF., CHARLES, P., GLUCINA, K. and MORLAY, C., 2012. The removal of endocrine disrupting compounds, pharmaceutically activated compounds and cyanobacterial toxins during drinking water preparation using activated carbon - a review. The Science of the Total Environment, vol. 435-436, p. 509-525. http://dx.doi.org/10.1016/j.scitotenv.2012.07.046. PMid:22885596

FENECH, C., NOLAN, K., ROCK, L. and MORRISSEY, A., 2013. An SPE LC-MS/MS method for the analysis of human and veterinary chemical markers within surface waters: an environmental forensics application. Environmental Pollution, vol. 181, no. 1, p. 250-256. http://dx.doi.org/10.1016/j.envpol.2013.06.012. PMid:23877039

FIGUEIREDO, JA., DRUMM, E., RODRIGUES, MA. and SPILKI, FR., 2010. The Rio dos Sinos watershed: an economic and social space and its interface with environmental status. Brazilian Journal of Biology $=$ Revista Brasileira de Biologia, vol. 70, supplement 4, p. 1131-1136. PMid:21225153.

Fundação Estadual de Proteção Ambiental Luiz Roessler-FEPAM, 2013. Qualidade ambiental - bacia do Rio do Sinos, relatório técnico. FEPAM. Available from: $<$ http://www.fepam.rs.gov.br/ qualidade/qualidade_sinos/sinos.asp $>$. Acess in: 31 Jul. 2013.

GHISELLI, G. and JARDIM, WF., 2007. Interferentes endócrinos no ambiente. Quimica Nova, vol. 30, no. 3, p. 695-706. http:// dx.doi.org/10.1590/S0100-40422007000300032.

JARDIM, WF., MONTAGNER, CC., PESCARA, IC., UMBUZEIRO, GA., DI DEA BERGAMASCO, AM., ELDRIDGE, ML. and SODRÉ, FF., 2012. An integrated approach to evaluate emerging contaminants in drinking water. Separation and Purification Technology, vol. 84, p. 3-8. http://dx.doi.org/10.1016/j.seppur.2011.06.020.

KIM, SD., CHO, J., KIM, IS., VANDERFORD, BJ. and SNYDER, SA., 2007. Occurrence and removal of pharmaceuticals and endocrine disruptors in South Korean surface, drinking, and waste waters. Water Research, vol. 41, no. 5, p. 1013-1021. http://dx.doi. org/10.1016/j.watres.2006.06.034. PMid:16934312

LINTELMANN, J., KATAYAMA, A., KURIHARA, N., SHORE, L. and WENZEL, A., 2003. Endocrine disruptors in the environment (IUPAC Technical Report). International Union of Pure and Applied Chemistry, vol. 75, no. 5, p. 631-681. http://dx.doi.org/10.1351/ pac200375050631.

LOPEZ-ESPINOSA, MJ., FREIRE, C., ARREBOLA, JP., NAVEA, N., TAOUFIKI, J., FERNANDEZ, MF., BALLESTEROS, O., PRADA, R. and OLEA, N., 2009. Nonylphenol and octylphenol in adipose tissue of women in Southern Spain. Chemosphere, vol. 76, no. 6, p. 847-852. http://dx.doi.org/10.1016/j.chemosphere.2009.03.063. PMid: 19409598

MITRA, S. (Ed.), 2003. Sample preparation techniques in analytical chemistry. New Jersey: John Wiley \& Sons Inc. 458 p. http://dx.doi. org/10.1002/0471457817.

MUNARETTO, JS., 2009. Determinação de disruptores endócrinos presentes no efluente doméstico de uma Instituição de Ensino Superior no Vale do Sinos - RS, antes e após Estação de Tratamento de Esgoto. Novo Hamburgo: Universidade Feevale. Trabalho de Conclusão de Curso em Ciências Farmacêuticas.

Purific, 2014. Purific, o melhor da água. Purific. Available from: $<$ http://www.purific.com.br>. Acess in: 31 Jul. 2013.

QUIGNOT, N., ARNAUD, M., ROBIDEL, F., LECOMTE, A., TOURNIER, M., CREN-OLIVÉ, C., BAROUKI, R. and LEMAZURIER, E., 2012. Characterization of endocrine-disrupting chemicals based on hormonal balance disruption in male and female adult rats. Reproductive Toxicology (Elmsford, N.Y.), vol. 33, no. 3, p. 339-352. http://dx.doi.org/10.1016/j.reprotox.2012.01.004. PMid:22285353

RIBEIRO, AM., ROCHA, CC., FRANCO, CF., FONTANA, LF. and PEREIRA NETTO, AD., 2012. Seasonal variation of polycyclic aromatic hydrocarbons concentrations in urban streams at Niterói City, RJ, Brazil. Marine Pollution Bulletin, vol. 64, no. 12, p. 2834-2838. http://dx.doi.org/10.1016/j.marpolbul.2012.09.014. PMid:23083927

SODRÉ, FF., LOCATELLI, MAF. and JARDIM, WF., 2010. Occurrence of emerging contaminants in Brazillian drinking waters: A sewage-to-tap Issue. Water, Air, and Soil Pollution, vol. 206, no. 1-4, p. 57-67. http://dx.doi.org/10.1007/s11270-009-0086-9.

TORRES, NH., 2009. Monitoração dos resíduos dos hormônios $17 \alpha$-etinilestradiol, 17ß-estradiol e estriol em águas de abastecimento 
urbano da cidade de Piracicaba, SP. Piracicaba: Universidade de São Paulo. Masters Dissertation in Science.

VIJAYA SARADHI, UVR., PRABHAKAR, S., JAGADESHWAR REDDY, T. and MURTY, MR., 2007. Gas chromatographic-mass spectrometric determination of alkylphosphonic acids from aqueous samples by ion-pair solid-phase extraction on activated charcoal and methylation. Journal of Chromatography A, vol. 1157, no.
1-2, p. 391-398. http://dx.doi.org/10.1016/j.chroma.2007.04.057. PMid:17507025

WANG, MH. and BASKIN, LS., 2008. Endocrine disruptors, genital development, and hypospadias. Journal of Andrology, vol. 29, no. 5, p. 499-505. http://dx.doi.org/10.2164/jandrol.108.004945. PMid:18497336 